Available online at: http://journal.unj.ac.id

Jurnal
Pensil

Journal homepage: http://journal.unj.ac.id/unj/index.php/ipensil/index

\title{
PENGEMBANGAN E-MODUL PADA MATA KULIAH KOMPETENSI PEMBELAJARAN DI PROGRAM STUDI PENDIDIKAN TEKNIK BANGUNAN, UNIVERSITAS NEGERI JAKARTA
}

\section{THE DEVELOPMENT OF TEACHING MATERIALS FOR ELECTRONIC MODULE OF LEARNING COMPETENCY IN BACHELOR DEGREE OF BUILDING ENGINEERING EDUCATION PROGRAM, UNIVERSITAS NEGERI JAKARTA}

Afaf Afifah

Universitas Negeri Jakarta, Jalan Rawamangun Muka, Jakarta Timur, DKI Jakarta 13120, Indonesia

afaf822@gmail.com

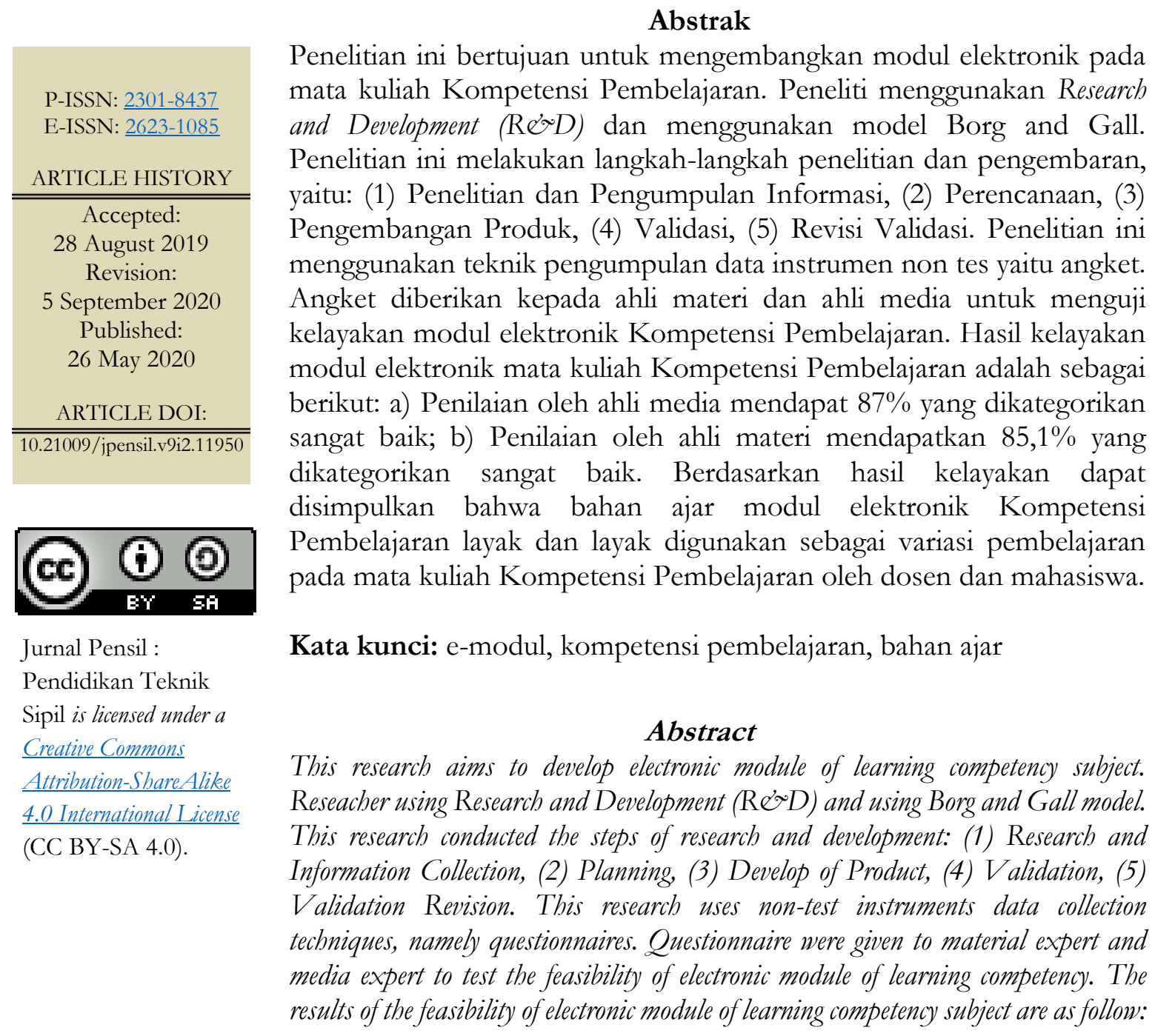


a) Assessment by media expert gets $87 \%$ which categorized as very good; b) Assessment by material expert gets $85,1 \%$ which categorized as very good. Based on the result of feasibility, can be concluded that the teaching material for electronic module of learning competency is appropriate and suitable for use as a variation of learning on learning competency subject by lecture and student.

Keywords: e-module, learning competency, teaching material

\section{Pendahuluan}

Perkembangan ilmu pengetahuan dan teknologi yang begitu cepat menuntut setiap manusia untuk memiliki sikap ulet dan disiplin dalam meningkatkan sumber daya. Kehadiran teknologi modern pada dunia pendidikan tidak memberikan pilihan selain untuk ikut serta memanfaatkannya. Dunia pendidikan harus terus ikut berkembang mengikuti perkembangan era modern saat ini agar tujuan pendidikan dapat tercapai secara maksimal. Pada era modern dan teknologi yang canggih menuntut para pengajar bersikap dinamis dalam mengikuti perkembangan teknologi. Menggunakan bahan ajar modern yang tepat merupakan satu kesatuan yang sangat berpengaruh dalam proses pembelajaran. Bahan ajar harus disesuaikan dengan kondisi peserta didik maupun strategi yang digunakan oleh pengajar. Prastowo (2014, pp. 95-113) menyatakan bahwa bahan ajar merupakan segala bahan baik informasi, alat, maupun teks yang disusun secara sistematis yang menampilkan sosok utuh dari kompetensi yang akan dikuasai oleh peserta didik dan digunakan dalam proses pembelajaran. Bahan ajar memiliki beberapa jenis yaitu bahan ajar cetak (buku, handout, brosur, modul, dan lembar kerja peserta didik) dan non cetak (audio, kaset, radio, multimedia pembelajaran interaktif, compact disk, bahan ajar berbasis web, e-modul) (Istiadah, 2020).

Penggunaan media dan juga bahan ajar merupakan komponen yang mempengaruhi pembelajaran karena berhasilnya suatu tujuan pembelajaran salah satunya adalah bagaimana seorang pengajar memilih dan menerapkan metode mengajar yang sesuai untuk peserta didiknya. Seorang pendidik juga harus dapat memilih media yang sesuai untuk mempermudah penyampaian materi yang mampu menimbulkan daya tarik peserta didik. Salah satu media pembelajaran interaktif saat ini adalah e-modul. Bahan ajar $e$ modul pada proses pembelajaran diharapkan akan membantu peserta didik untuk belajar secara mandiri di luar proses pembelajaran di kelas juga agar mampu memahami materi sepenuhnya. Pengembangan e-modul berdampak pada proses pembelajaran peserta didik yang mana dapat dengan leluasa mempelajari materi yang telah disediakan dalam e-modul untuk memperluas pengetahuan terhadap materi tersebut dengan demikian dapat mempermudah proses pembelajaran di dalam kelas.

E-modul pada hakikatnya sama dengan modul biasa yaitu satu unit program pembelajaran yang terencana, didesain guna membantu peserta didik mencapai tujuan pelatihan. Pembeda e-modul dengan modul biasa hanya e-modul merupakan modul dengan tingkat kompleksitasnya secara elektronik. Memberikan e-modul pada peserta didik akan membantu peserta didik dalam pembelajaran secara mandiri, karena modul itu sendiri bersifat self-contained dan selfinstruction (kegiatan belajar mandiri) (Riyadi, 2017). E-modul yang akan dikembangkan terdiri dari rencana belajar, tujuan pembelajaran, uraian materi, dan juga evaluasi. Pembuatan e-modul yaitu untuk membuat peserta didik dengan mudah mempelajari materi yang akan di ajar dan melatih kemandirian peserta didik untuk belajar sendiri ketika waktu senggang. 
Sesuai dengan penjelasan diatas, yang bersamaan sedang dikembangkannya situs elearning moodle pada Program Studi Pendidikan Teknik Bangunan untuk menunjang kegiatan akademik, maka akan dikembangkannya e-modul pada Mata Kuliah Kompetensi Pembelajaran. Kompetensi Pembelajaran merupakan salah satu mata kuliah wajib yang harus diikuti oleh mahasiswa Program Studi Pendidikan Teknik bangunan di Universitas Negeri Jakarta. Tujuan dari mata kuliah kompetensi pembelajaran adalah mahasiswa dapat menguasai ketrampilan mengajar dan mampu mengajar dengan baik. Selama ini media pembelajaran dan sumber belajar mata kuliah kompetensi pembelajaran berupa bahan ajar cetak dan juga power point atau PPT. Salah satu kelemahan masih menggunakan media konvensional seperti bahan ajar cetak untuk mahasiswa yaitu mahasiswa tidak mudah untuk mengulang kembali materi yang diajarkan saat proses pembelajaran di kelas.

Pada pendahuluan dari pengamatan peneliti telah dilakukan penyebaran angket analisis kebutuhan kepada mahasiswa mahasiswa yang telah dan sedang mengikuti mata kuliah Kompetensi Pembelajaran dengan hasil $82,1 \%$ mahasiswa menginginkan pengembangan e-modul pada mata kuliah Kompetensi Pembelajaran. Selain itu pertimbangan utama dari pemilihan mata uliah kompetensi pembelajaran, data hasil belajar pada semester 106 dan semester 108. Data yang didapat menunjukkan bahwa terdapat 6 mahasiswa yang mendapatkan nilai A pada semester 106 dan 11 mahasiswa pada semester 108, pada semester 106 terdapat 7 mahasiswa yang mendapatkan $\mathrm{B}+$ sedangkan terdapat 4 mahasiswa pada semester 108, dan pada semester 108 terdapat 1 mahasiswa yang mendapatkan nilai $C$ sedangkan pada semester 106 tidak ada mahasiswa yang mendapatkan nilai $\mathrm{C}$.

Pada penjelasan tersebut dapat disimpulkan bahwa, terdapat kenaikan nilai A tetapi terjadi penurunan pada nilai A- dan juga masih terdapat mahasiswa yang mendapatkan nilai C. Oleh karena itu, mata kuliah Kompetensi Pembelajaran dijadikan mata kuliah yang akan dikembangkan bahan ajarnya oleh peneliti, dengan tujuan pada semester yang akan datang diharapkan mahasiswa mendapatkan persentase kelulusan mencapai 100\% dan persentase mahasiswa yang mendapatkan nilai $\mathrm{A}$ meningkat.

Berdasarkan uraian tersebut, penelitian ini akan mengembangkan media dan sumber belajar yaitu dengan pengembangan $e$-modul dengan pembelajaran berbasis web dengan situ e-learning yang sedang dikembangkan oleh Program Studi Pendidikan Teknik Bangunan, Universitas Negeri Jakarta. Pengembangan bahan ajar ini diharapkan dapat membantu mahasiswa di dalam menguasai materi Kompetensi Pembelajaran dengan mengakses melalui $e$ modul. Selain itu pengembangan bahan ajar $e$ modul ini juga diharapkan akan memotivasi mahasiswa agar dapat belajar lebih giat.

Berdasarkan latar belakang masalah yang diuraikan di atas, maka dapat diidentifikasi beberapa masalah berikut yaitu, (1) Kurang memanfaatkan teknologi komunikasi yang ada dalam proses pembelajaran, (2) Bahan ajar pada mata kuliah kompetensi pembelajaran harus menyesuaikan perkembangan era teknologi, dan (3) Bahan ajar pada mata kuliah kompetensi pembelajaran belum mempunyai e-modul.

Berdasarkan identifikasi masalah peneliti membatasi masalah pada beberapa hal berikut yaitu (1) Peneliti hanya mengembangkan bahan ajar e-modul Kompetensi Pembelajaran pada Program Studi Pendidikan Teknik Bangunan, Universitas Negeri Jakarta. (2) Penelitian pada bahan ajar yang telah selesai dikembangkan hanya sampai dilakukan uji validasi oleh ahli media dan ahli materi. (3) Penelitian pada bahan ajar yang telah selesai direvisi akan ditautkan pada e-learning moodle.

Berdasarkan batasan masalah, maka rumusan masalah didapat: Bagaimana Pengembangan e-modul pada mata kuliah Kompetensi Pembelajaran pada Program 
Studi Pendidikan Teknik Bangunan, Universitas Negeri Jakarta.

Penelitian ini dapat diharapkan dapat memberikan manfaat baik teoritis maupun praktis. Adapun manfaat Teoritis yaitu (1) Sebagai masukan untuk mendukung dasar teori bagi penelitian sejenis dan relevan tentang pengembangan bahan ajar e-modul. (2) Sebagai bahan pustaka bagi mahasiswa program studi S1 Pendidikan Teknik Bangunan di Universitas Negeri Jakarta. Sedangkan pada manfaat praktis yaitu (2) Dijadikan salah satu pilihan bahan ajar untuk Mata Kuliah Kompetensi Pembelajaran. (3) Meningkatkan pengetahuan tentang pengembangan bahan ajar berbasis. e-modul mata kuliah Kompetensi Pembelajaran.

Bahan Ajar

Bahan ajar adalah isi yang diberikan kepada peserta didik pada saat berlangsungnya proses belajar mengajar. Melalui bahan pelajaran ini peserta didik diantarkan kepada tujuan pengajaran (Sudjana, 2009). Dapat dikatakan bahwa bahan ajar merupakan isi atau materi pembelajaran yang telah disusun oleh pendidik secara lengkap dan sistematis. Bahan ajar bersifat sistematis artinya adalah bahan ajar telah disusun secara urut untuk memudahkan peserta didik memahami pembelajaran dan materi yang diajar. Bahan ajar mempunyai fungsi yang sangat penting dalam kegiatan pembelajaran, seperti: (1) memberikan petunjuk yang jelas bagi pembelajar dalam mengelola kegiatan belajar mengajar, (2) menyediakan bahan/alat yang lengkap yang diperlukan untuk setiap kegiatan, (3) merupakan media penghubung antara pembelajaran dan pelajar, (4) dapat dipakai oleh pelajar sendiri dalam mencapai kemampuan yang telah ditetapkan, (5) dapat dipakai sebagai program perbaikan (Syairi, 2013).

Bahan ajar memiliki beberapa jenis, secara garis besar bahan ajar dikelompokkan dalam dua kelompok yaitu, bahan ajar cetak dan bahan ajar non cetak. Menurut Prastowo (2014, pp. 95-113) mengelompokkan bahan ajar berdasarkan bentuknya, di antaranya (1)
Bahan ajar cetak, merupakan bahan ajar yang berbentuk kertas untuk keperluan pembelajaran atau menyampaikan sebuah informasi. Misalnya, handouts, lembar kerja peserta didik, bahan belajar mandiri, bahan untuk belajar kelompok, modul cetak. (2) Bahan non cetak, merupakan bahan ajar yang tidak memerlukan dicetak untuk menggunakannya. Misalnya e-modul. (3) Bahan Ajar pandang dengar atau audiovisual merupakan penggabungan antara sinyal audio dengan gambar bergerak secara sekuensial. Misalnya, film, video compact disk. (4) Bahan ajar yang dibutuhkan untuk keperluan interaktif manusia, terutama untuk keperluan Pendidikan jarak jauh. Misalnya, telepon, handphone, video conferencing, dan lain sebagainya.

\section{Modul Pembelajaran}

Menurut Nasuiton (2015) dalam bukunya menyatkan bahwa modul merupakan suatu unit yang lengkap yang berdiri sendiri dan terdiri atas suatu rangkaian kegiatan belajar yang disusun untuk membantu siswa dalam mencapai sejumlah tujuan yang dirumuskan secara khusus dan jelas.

Sebuah modul maupun e-modul pembelajaran harus memiliki kriteria seperti yang diungkapkan oleh Sanjaya (2015) dalam sebuah modul minimal berisi: (1) Tujuan yang harus dicapai, yang biasanya dirumuskan dalam bentuk perilaku yang spesifik sehingga keberhasilannya dapat diukur. (2) Petunjuk penggunaan yakni petunjuk bagaimana siswa belajar modul. (3) Kegiatan belajar, berisi tentang materi yang harus dipelajari oleh siswa. (4) Rangkuman materi, yakni garis-garis besar materi pelajaran. (5) Tugas dan latihan. (6) Sumber bacaan, yakni buku-buku bacaan yang harus dipelajari untuk mempelajari untuk memperdalam dan memperkaya wawasan. (7) Item-item tes, soal-soal yang harus dijawab untuk melihat keberhasilan siswa dalam penguasaan materi pelajaran. (8) Kriteria keberhasilan, yakni rambu-rambu keberhasilan siswa dalam mempelajari modul. 


\section{E-Modul}

Modul elektronik atau e-modul dapat didefinisikan sebagai sebuah bentuk penyajian bahan belajar mandiri yang disusun secara sistematis ke dalam unit pembelajaran demi mencapai tujuan dari pembelajaran tertentu yang disajikan secara elektronik, dimana kegiatan pembelajaran lebih interaktif dengan menghubungkan link - link video maupun animasi - animasi yang membuat peserta didik lebih interaktif dengan program dan memberikan pengalaman belajar.

\section{Pengembangan E-modul}

Pengembangan merupakan sebuah usaha yang sistematis untuk menciptakan suatu program dan juga produk yang diharapkan dapat mencapai tujuan pembelajaran. Kesimpulan tersebut dapat dikatakan bahwa pengebangan pada akhirnya akan menciptakan suatu produk.

Pengembangan teknologi pendidikan berujung pada produksi media di antaranya media cetak, teknologi audio visual, teknologi berbasis komputer, dan juga teknologi terpadu. Dalam penelitian ini, pengembangan e-modul merupakan dari pengembangan teknologi terpadu. Pengembangan e-modul yang dimaksudkan adalah cara memproduksi bahan ajar berisikan teks, gambar, video tutorial, dan juga animasi dengan prinsip pengembangan bahan ajar mandiri yaitu modul yang dioperasikan dengan menggunakan bantuan komputer, sehingga dapat disebut sebagai modul elektronik atau e-modul.

Model Pengembangan Produk

Pembelajaran

Pada pengembangan sebuah produk diperlukannya langkah-langkah untuk dijadikan sebagai acuan dalam proses pengembangan. Terdapat berbagai model pengembangan instruksional, Gustafson and Brach mengelompokkan model berdasarkan karakteristik tertentu (Kruse, 2010). Ada yang berorientasi pada kelas atau classroomoriented seperti, model Morrison, Ross and
Kemp, ada juga yang berorientasi pada pengembangan produk atau productoriented seperti, model Seels and Glasgow, ataupun berorientasi pada sistem atau system-oriented seperti, model Carey and Dick (Gunadharma, 2019). Secara keseluruhan semua model pengembangan memiliki lima komponen dasar yaitu ADDIE: Analyse, Design, Development, Implementation, Evaluation, walaupun tidak semua model memiliki urutan yang sama.

\section{Model Pengembangan E-modul}

Berdasarkan beberapa model pengembangan produk di atas, pada dasarnya setiap model pengembangan memiliki karakteristiknya masing - masing. Terlepas dari berbagai langkah yang diterapkan dalam masing - masing model tersebut, pada dasarnya model pengembangan merupakan acuan yang sama. Penulis merasa bahwa model yang sesuai dengan pengembangan produk e-modul yang peneliti kembangkan adalah model Borg and Gall. Berdasarkan tahapan penelitian dan pengembangan yang dikembangkan oleh Borg and Gall, peneliti melakukan penyederhanaan dan pembatasan menjadi lima tahapan. Penelitian ini dibatasi hingga tahapan revisi produk setelah dilakukannya uji coba terbatas terhadap mahasiswa dan juga para ahli media, dan ahli materi. Penyederhanaan dan pembatasan tahapan menjadi tujuh disandingkan dengan pendapat Borg and Gall yang menyarankan dalam penelitian untuk jenjang Strata 1, penelitian dibatasi dalam skala kecil yaitu sampai dihasilkannya produk setelah diuji coba terbatas.

Modul harus disusun secara baik dan benar sehingga tujuan dari modul itu tersebut dapat tercapai, dalam menyusun sebuah modul ada beberapa langkah yang harus dilalui (Prastowo, 2014), di antaranya (1) Analisis Kurikulum, Langkah awal ini dimaksudkan untuk menentukan materi mana dari hasil pemetaan standar kompetensi, kompetensi dasar, dan indikator. (2) Penentuan Judul, dalam menyusun modul adalah menentukan judul 
modul. Untuk menentukan judul modul maka harus sesuai dengan kompetensi dasar atau materi yang ada dalam silabus. (3) Pemberian kode modul, kode modul digunakan untuk memudahkan penggunaan dari modul itu sendiri. (4) Penulisan modul, ada lima hal yang dijadikan acuan dalam proses penulisan modul, yaitu: (a) Perumusan kompetensi dasar yang harus dikuasai, (b) Menentukan alat evaluasi atau penilaian, (c) Penyusunan Materi, (d) Urutan pengajaran, perlu diketahui bahwa dalam kaitannya dengan urutan pengajaran, maka hal ini dapat diberikan dalam petunjuk menggunakan modul, (e) Struktur bahan ajar (modul), secara umum modul membuat paling tidak tujuh komponen utama yaitu, judul, petunjuk belajar (untuk siswa dan guru), kompetensi yang akan dicapai, informasi pendukung, latihan, petunjuk kerja berupa lembar kerja (LK), evaluasi. Tetapi, modul dapat banyak bervariasi tidak hanya berpacu dengan tujuh komponen tersebut (Prastowo, 2014).

\section{Materi Kompetensi Pembelajaran}

Kompetensi pembelajaran merupakan salah satu mata kuliah wajib yang ada pada program studi Pendidikan Teknik bangunan di Universitas Negeri Jakarta. Kompetensi Pembelajaran merupakan mata kuliah berlanjut setelah sebelumnya mahasiswa mempelajari Perencanaan Pembelajaran dan Evaluasi Pembelajaran. Tujuan dipelajari mata kuliah Kompetensi Pembelajaran untuk mahasiswa adalah agar mahasiswa memahami cara mengajar yang benar dan profesional. Lulusan dari program studi Pendidikan Teknik bangunan diharapkan akan menjadi guru di SMK bangunan. Maka dari itu, pemahaman mahasiswa terhadap cara mengajar haruslah dilatih dengan baik salah satunya dengan mata kuliah kompetensi pembelajaran. Mata kuliah kompetensi pembelajaran sendiri menuntut mahasiswa untuk menguasai cara mengajar yang baik dengan diadakannya microteaching pada pertengahan semester hingga akhir semester. Demikian, mahasiswa harus menguasai materi dengan baik sebelum microteaching dimulai.

\section{Metode Penelitian}

Penelitian ini menggunakan metode Penelitian dan Pengembangan (Research and Development). Menurut Sugiyono (2015) Research and Development atau metode penelitian dan pengembangan merupakan metode yang digunakan untuk menghasilkan produk tertentu, dan menguji keefektifan produk tersebut. Untuk dapat menghasilkan produk tertentu digunakan penelitian yang bersifat analisis kebutuhan (digunakan metode kualitatif) dan untuk menguji keefektifan produk tersebut supaya dapat berfungsi di masyarakat luas, maka diperlukan penelitian untuk menguji keefektifan produk tersebut. Jadi secara singkat, penelitian dan pengembangan merupakan metode penelitian yang akan menghasilkan sebuah produk yang akan divaliditaskan oleh tim ahli yang selanjutnya akan diuji coba langsung di lapangan.

Pada penelitian ini menggunakan model penelitian Borg and Gall yang disederhanakan menjadi tahapan Level 1. Modul penelitian ini terdiri dari lima tahapan yaitu studi pendahuluan (research and information collectiong), tahapan perencanaan (planning), tahapan pengembangan desain (develop preliminary of product), tahapan validasi (validation test), tahapan revisi validasi (main product revision).

\section{Hasil Penelitian dan Pembahasan}

Penelitian ini memiliki tujuan yaitu untuk menghasilkan produk berupa bahan ajar e-modul Kompetensi Pembelajaran. Emodul ini disusun berdasarkan kompetensi inti yang telah diberikan oleh dosen pengampu. Pada e-modul terdapat animasi animasi yang menarik, deskripsi keseluruhan e-modul, uraian materi, latihan soal atau evaluasi beserta kunci jawabannya, daftar pustaka dan juga terdapat beberapa kegiatan interaktif seperti klik dan juga link yang menyambungkan pada video yang berisikan materi dari sumber yang dapat digunakan 
dalam pembelajaran oleh mahasiswa agar lebih menarik.

$$
\text { Pada penelitian ini peneliti }
$$
menggunakan prosedur penelitian dan pengembangan dengan metode Research and Development (R\&D). Penelitian dan pengembangan ini bertujuan untuk menghasilkan produk e-modul peneliti menggunakan prosedur penelitian dan pengembangan Borg and Gall yang telah dimodifikasi dan dirangkum menjadi lima langkah penelitian dan pengembangan yaitu, studi pendahuluan, tahapan perencanaan, desain produk, validasi dengan ahli, revisi produk.

Penilaian produk melalui validasi dilakukan oleh dua orang ahli media dan tiga orang ahli materi yang kompeten dalam bidangnya masing-masing. Persentase kelayakan yang didapat dari validasi ahli materi yaitu sebesar $87 \%$ yang berarti $e$-modul dinyatakan "Sangat Baik", berarti bahan ajar yang dikembangkan yaitu bahan ajar berbentuk e-modul ini baik untuk digunakan sebagai media pembelajaran Kompetensi pembelajaran. Pada ahli materi persentase yang didapat yaitu $85,1 \%$ yang berarti "Sangat Baik", e-modul memenuhi kriteria layak dan dinyatakan secara keseluruhan materi yang disajikan dalam bahan ajar berbasis e-modul ini sesuai dan juga layak untuk mata kuliah Kompetensi Pembelajaran.

Setelah tahap validasi ahli dilakukan langkah selanjutnya yaitu perbaikan desain atau revisi produk. Perbaikan yang dilakukan sesuai dengan komentar atau saran yang diberikan oleh validator. Perbaikan dilakukan dengan tujuan untuk memperbaiki produk sehingga yang dihasilkan lebih baik dari sebelumnya.

\section{Kelebihan dan Kekurangan Produk}

\section{A. Kelebiban Produk Hasil Pengembangan}

Produk pengembangan ini memiliki beberapa kelebihan, yaitu:

1. E-modul yang dikembangkan dapat memberikan wawasan pengetahuan kepada mahasiswa baik dari segi materi
Kompetensi Pembelajaran maupun segi teknologi karna e-modul akan dimasukkan ke dalam moodle.

2. E-modul berbentuk softcopy yang mana akan memudahkan untuk diakses dimanapun. File e-modul dapat disimpan dan mahasiswa dapat dengan fleksibel menggunakannya.

3. Pada e-modul terdapat animasi dan juga link video untuk ditonton oleh mahasiswa agar memudahkan mempelajari materi yang ada.

\section{B. Kekurangan Produk Hasil Pengembangan}

Adapun kekurangan dari produk yang dikembangkan, yaitu pada penelitian dan pengembangan ini hanya sebatas dilakukannya revisi validasi, belum melakukan uji coba lapangan maupun uji coba skala besar. Sehingga belum diketahui tanggapan mahasiswa terhadap produk emodul ini.

\section{Simpulan}

Berdasarkan hasil penelitian dan pengembangan pada Pengembangan Emodul Pada Mata Kuliah Kompetensi Pembelajaran di Program Studi Pendidikan Teknik Bangunan dapat disimpulkan bahwa hasil dari validasi yang dilakukan oleh ahli media menunjukkan bahwa e-modul sangat layak untuk digunakan sebagai alat bantu dalam proses pembelajaran dan juga sebagai variasi media pembelajaran. Pada hasil validasi ahli materi menunjukkan bahwa materi yang ada pada e-modul sudah dalam kategori baik untuk digunakan sebagai bahan ajar untuk mata kuliah Kompetensi Pembelajaran.

Pada penelitian dan pengembangan ini tidak dilakukan uji coba produk pada mahasiswa dikarenakan keterbatasan waktu, oleh karena itu penelitian dan pengembangan ini hasil sebatas hasil nilai dari validasi ahli materi dan ahli media. Secara keseluruhan setelah melalui uji validasi dan juga revisi validasi dapat disimpulkan bahwa e-modul pada mata kuliah kompetensi pembelajaran di program studi pendidikan teknik bangunan layak untuk 
digunakan sebagai satu variasi bahan ajar pada mata kuliah Kompetensi Pembelajaran.

\section{Daftar Pustaka}

Gunadharma, A. (2019, Juli 18). Pengembangan Modul Elektronik sebagai Sumber Belajar untuk Mata Kuliah Multimedia Design. Retrieved from [Online]:

http://id.linkedin.com/in/anandagun adharma

Istiadah, F. (2020). Teori-Teori Belajar dalam Pendidikan. Tasikmalaya: Edu Publisher.

Kruse, K. (2010). The Use of Traditional Instructional Systems Design Models for eLearning. The Herridhe Group.

Nasution, S. (2015). Berbagai Pendekatan Dalam Proses Belajar Mengajar. Jakarta: Bumi Aksara.
Prastowo, A. (2014). Paradigma Baru Madrasah dalam Implementasi Kebijakan Kurikulum 2013. Jurnal Pendidikan Islam 3(1), 95-113.

Riyadi, S. (2017). Efektivitas E-Modul Analisis Real Pada Program Studi Pendidikan Matematika Universitas Negeri Kanjuruhan Malang. Supremum Journal of Mathematics Education (SJME) 1(1), 31-40.

Sanjaya, W. (2015). Perencanaan dan Desain Sistem Pembelajaran. Jakarta: Kencana Prenadamedia Group.

Sudjana, N. (2009). Penilaian Hasil Proses Belajar Mengajar. Bandung: Remaja Rosdakarya.

Sugiyono. (2015). Metode Penelitian Pendidikan: Pendekatan Kuantitatif, Kualitatif, dan R\&D. Bandung: Alfabeta.

Syairi, K. (2013). Pengembangan Bahan Ajar Bahasa Arab. Jurnal Dinamika Ilmu 13(1), 51-66. 